\title{
The Socio-Political Implications of the Syrian Refugee Crisis on Jordan: 2011-2018
}

\author{
Mohammed Torki Bani Salameh ${ }^{1}$, Walid Khalid Abudalbouh ${ }^{2} \&$ Raya Farid Al-Silwani ${ }^{3}$ \\ ${ }^{1}$ Political Science Department, Yarmouk University, Irbid, Jordan \\ ${ }^{2}$ International Relations Department, Faculty of International Studies, University of Jordan, Jordan \\ ${ }^{3}$ Ministry of Environment, Head of International Section, Amman, Jordan; Part Time Lecturer, University of \\ Jordan, Jordan \\ Correspondence: Mohammed Torki Bani Salameh, Political Science Department, Yarmouk University, Irbid, \\ Jordan.E-mail: mohammadtorki@yu.edu.jo; mohammedtorki@yahoo.com
}

Received: December 30, 2019

Accepted: January 23, $2020 \quad$ Online Published: February 29, 2020

doi:10.5539/jpl.v13n1p89

URL: https://doi.org/10.5539/jpl.v13n1p89

\begin{abstract}
The aim of this study is to shed light on the socio- political effects of the Syrian refugee crisis on Jordan. The study tackles the socio political impact of the flow of hundreds of thousands of Syrian refugees to Jordan during the past nine years.

The study is based on a mixed approach, the descriptive and the historical. The results of the study show that the Syrian refugee crisis has politically and socially affected Jordan negatively. What makes matters worse and deepens the effects of the crisis in Jordan is the inability of the successive governments to deal strategically with the crisis. The study concluded with some suggested recommendations that may mitigate the negative impact of the crisis on Jordan.
\end{abstract}

Keywords: the Syrian crisis, socio political effects, Jordan, Arab Spring

\section{Introduction}

The Syrian refugee crisis is considered one of the largest, longest, and most complex humanitarian crisis in the $21^{\text {st }}$ century. Statistics show that more than 12 million Syrians have fled to a number of Arab and Western countries since June, 2011. The number of refugees in Jordan exceeded 1.4 million, which is equivalent to $14 \%$ of Jordan's population. (Bani Salameh and Hayajneh, 2019).

With the increasing number of refugees in Jordan, the country also faced an increase in the pressures it had originally, due to the scarcity of resources, which, in turn, has created many economic problems, such as: poverty, unemployment, deficit in the state's budget, and an additional pressure on the health and education infrastructure.

The increasing wave of Syrian refugees has also led to significant socio-political effects, such as: the decline of the democratic process, an increased threat to Jordanian national security, and the fear of terrorist attacks on Jordan, which requires more security measures and expenditures. The waves of Syrian refugees and asylum seekers have also played a role in imposing a threat on the Jordanian national identity, increased the rate of violence and extremism, increased corruption, and imposing a threat on the social fabric of Jordan with many unethical social practices, such as: drug trafficking, begging, and prostitution, which are all alien to the Jordanian society. Finally, this rising wave of Syrian immigration to Jordan has also led to several environmental problems.

\section{Research Problem}

The issue of Syrian refugees in Jordan has received great public and official attention due to the brotherly links between the two peoples. The sudden and intense refugee movement to Jordan has had a direct impact on the economic, social, political, and environmental conditions, which in turn inflicted an economic burden on Jordanians by increasing the prices of food, medicine, goods and services, low domestic wage rates. It also increased financial pressures, caused high levels of environmental degradation, increased begging, caused a

\footnotetext{
${ }^{1}$ Bani Salameh, M. T. and Hayajneh, A. (2019). How Jordan Can Cope

The End of the Syrian Civil War. Middle East Quarterly, Summer. https://www.meforum.org/58683/end-syrian-civil-war-jordan
} 
spread of illicit drug, and caused the proliferation of unethical practices. This study seeks to answer the following main question: "What is the size of the socio- political burden borne by the state and the Jordanian people as a result of Syrian refugee crisis?

\subsection{The Importance of the Study}

The tragedy of the Syrian refugees represented one of the dimensions of a widespread political crisis in the Arab world, and it raised many difficult questions at the academic level. Political demography also came to the scene in an attempt to explain this phenomena; not only because the crisis requires finding appropriate solutions, but because of the implications of the issues and problems of re-settling the refugees, and its (the Syrian refugee crisis) impact on development, political stability, and community reconciliation in the countries sending and receiving refugees. (Bani Salameh and Alkatatsheh, 2019).

As known, each study has a scientific and practical importance it tries to provide. This study's importance shows through its usefulness to everyone concerned about the effects and consequences of the Syrian refugee crisis on Jordan, and it includes; decision makers, opinion leaders, researchers, academics, and students,

1) On the theoretical level, the study deals with the issue of the Syrian refugee crisis and its various effects on Jordan, and it explains the international community's position on the crisis, as a humanitarian crisis that does not concern the Jordanian state alone. The study also deals with the crisis of Syrian refugees in Jordan in an organized and scientific manner based on facts and figures.

2) On the practical level, this study is not only a descriptive analysis of the concepts and dimensions of the problem, but it aims to reveal the effects of the Syrian refugee crisis on Jordan by determining the relationship between the crisis and the socio- political situation in Jordan throughout the period of study (2011-2018). The study will then subject that to analysis to identify whether the crisis was a challenge to Jordan and negatively affected the country, or if it was an opportunity for Jordan to benefit from?

3) Both theoretically and practically, this study's importance stems from revealing the dimensions and implications of the Syrian refugee crisis on Jordan in its positive and negative aspects, thus turning the general theoretical debate, which is not scientifically proven, into scientific facts that are tested with evidence and proof, to make the right decision through the right scientific debate, away from improvisation, speculation, or provision.

\subsection{Objectives of the Study}

The study aims to achieve the following objectives:

1) To identify the socio- political impact of the Syrian refugee crisis on Jordan.

2) To recognize Jordan's national and humanitarian role in securing the basic rights of Arab refugees in general.

3) To make recommendations and propose solutions to the decision makers in Jordan, that will contribute in alleviating the effects of the Syrian refugee crisis in Jordan.

\subsection{Study Hypothesis}

The study is based on the following main hypothesis:

The study assumes that the number of Syrian refugees is the independent variable, and the socio- political dimensions are the dependent variables. There is a positive correlation between the increase in the number of Syrian refugees in Jordan and the increase in political tensions and political instability, the retreat of the democratic process, and the spread of corruption, extremism, and tension. These dimensions have been adversely affected by the consequences of the refugee crisis.

\subsection{Methodology of the Study}

This study uses the analytical descriptive approach: to describe the phenomenon of Syrian refugee crisis to Jordan, and to identify the dimensions and consequences of this crisis and its impact on Jordan and draw the consequences thereof, in addition to describing the Jordanian experience in dealing with refugee issues before the Syrian crisis.

\subsection{The Limits of the Study}

The time, spatial and subject limits of the study are as follows:

1) The time limit for this study is seven years- from 2011 to 2018. The year 2011 marks the beginning of the Syrian crisis and the beginning of the influx of Syrian refugees into Jordan. The year 2018 represents the crisis

\footnotetext{
${ }^{2}$ Bani Salameh, M. T. and Alkatatsheh, M. H. (2019). The Politics of Migration from the Arab Spring Countries to Europe. Dirasat: Human and Social Sciences, 46(4): 2019-106.
} 
reaching its Eighth year and its increasing complexity, along with the weak prospects for reaching a solution in the near future, therefore the possibility of its continuation in the upcoming years.

2) The spatial limit of the study is the Hashemite Kingdom of Jordan- as the host country for the Syrian refugees, and the Syrian Arab Republic, which is witnessing a civil war; one of its most prominent results being the migration of Syrians to neighboring countries, including Jordan.

3) The study subject will be limited to addressing the socio- political effects of the Syrian refugee crisis on Jordan.

\section{Literature Review}

There are many studies that dealt with the issue of Syrian refugee crisis on Jordan, but they were all about the effects of the crisis in terms of the economic aspects, such as: the effects of the crisis on the labor market, and the impact of the crisis on economic and social stability, especially in times of crisis, and we note the scarcity of Jordanian studies that dealt with the subject in terms of its socio-political aspects, either directly or indirectly, but there are a number of studies that tried to approach the content and objectives of this study, and from these studies we mention the following:

1) Razan and Symansky study entitled, the Financial Impact of Syrian Refugees on the Jordanian Economy (Nasser and Symansky, 2015).

The study aimed to measure the direct and indirect financial impact of Syrian asylum to Jordan in the sectors of water, electricity, schools, universities, infrastructure, and security costs. The study estimated that the Jordanian government increased spending, by 1\% of GDP in 2013 and 2014, on the humanitarian needs of Syrian refugees, including: water, electricity, security, health care, and education services.

The study estimated that restoring the quality of public services to pre-crisis levels could have led to additional fiscal spending of $0.6 \%$ of GDP in 2013 and 1\% of GDP in 2014, Which are necessary to ensure that the situation for Jordanians doesn't worsen, compared with the previous situation of the flow of refugees.

The study also pointed out that the crisis increased the volume of commodity imports to meet the needs associated with the population increase by more than $11 \%$ in 2013 . The decrease in exports is due to the loss of a major export route through Syria to Europe and other countries of the region by 30\% in 2013. However, what eased the impact on the current account is the relief offered from aid agencies and the transfers from individuals to support refugees. The study considered that the rise in rental prices by $7.7 \%$ contributed to the rise in inflation and increased the suffering of Jordanians.

2) Stephen Eric and Solveig Hillesund study entitled, the impact of Syrian asylum on the Jordanian labor market (Eric and Solveig Hillesund, 2015).

This study included an analysis of the impact of the Syrian refugee crisis on the Jordanian labor market. The analysis was based on a specific random sample in the capital Governorate Amman, and Mafraq, and Irbid. It also used a methodology that linked the interviews of specialists and the distribution of a questionnaire in the three governorates. The analysis included an indication of the economic impacts, such as: the impact on the number of jobs and opportunities available, and the future prospects of the impact of Syrian labor on the Jordanian economy.

3) Jeffrey Frankens' study entitled, assessing the Impact of the Syrian Refugee Crisis on Stability and Resiliency in Jordanian Host Communities: Preliminary Impact Assessment (Frankens, 2014).

The study aimed to identify the effects of the Syrian refugee crisis on Jordan in general, and on the Jordanian society in the North region, in particular; as the region bordering Syria and the most affected by the crisis of Syrian asylum to the country.

The study showed that the long-standing Syrian crisis has caused a large influx of refugees to Jordan. By the end of 2013 , the number reached more than half a million refugees, or $9 \%$ of Jordan's population in general. Despite the support and assistance provided to Jordan to aid in its hosting of Syrian refugees, the situation of the country in general and the host communities in the North in particular is under severe pressure, as the demand for services

\footnotetext{
${ }^{3}$ Razan Nasser and Steven Symansky, The Fiscal Impact of the Syrian Refugee Crisis on Jordan, United States Agency for International Development Jan 5- 2015.

${ }^{4}$ Stephen Eric and Solveig Hillesund, Impact of Syrian Refugees on the Jordanian Labor Market, International Labor Organization and FAFO, April 2015.

${ }^{5}$ Jeffrey Frankens Evaluating the Effects of the Syrian Refugee Crisis on Stability and Resilience in Jordan: Host Communities Preliminary Impact Assessment. 2014, at the following link https://data.inhcr.orgtsyrianrctugees/downloadphp/
} 
increased due to the sudden increase in population. The study sought an initial assessment of aid to Jordan in order to prioritize host communities to support flexibility, stability, and ease of tension.

The main findings of the study are that the main factors of tension in host societies are: securing livelihoods, the competition for jobs, the competition of finding affordable housing, the challenges in the education sector, that began to deteriorate as a result of increasing numbers of students. As a result of the of Syrian refugee crisis sectors of health, water, and solid waste were severely affected. All of which pose challenges to society in general, increase tension, and affect the degree of stability. The study pointed out that Jordan suffered from weak infrastructure before the crisis of Syrian asylum which exacerbated the crisis and multiplied its effects.

4) Doris Carrion's study entitled, Syrian Refugees in Jordan: Facing the Difficult Facts (Carrion, 2015):

The study sought to find out the political, economic, and social repercussions of the long-term Syrian asylum in Jordan. The study relied on interviews with more than $70 \mathrm{UN}$ officials and international institutions, officials of the Jordanian government, as well as with analysts, journalists and civil society organizations.

The study showed that the Syrian refugee crisis is the second crisis that Jordan has faced in ten years. It had already received Iraqi refugees in 2003. Prior to that, Jordan had received previous waves of refugees from war-torn countries. Jordan received hundreds of Iraqi and Palestinian refugees displaced by the 1991 Gulf war and Arab-Israeli wars in the years 1967-1948.

\subsection{Comment on Previous Studies}

The researchers noted from his reading of the literature review of previous studies, that there is a wide disparity in the number of studies that dealt with the economic and social effects of the Syrian refugee crisis, and the studies that dealt with its political impacts. This confirms the importance of this study, where it is noted through previous studies that there is a lack of special studies that have been fully concerned with the identification of the socio-political effects of the Syrian refugee crisis on Jordan. According to what the researchers has reviewed, despite the existence of a number of previous studies that tackled more than one dimension of the Syrian refugee crisis to Jordan, there was no study that focused on the socio- political effects of the Syrian refugee crisis on Jordan, therefore this study is necessary in light of the following considerations:

- Most studies emphasized the economic, financial, and social effects of the Syrian asylum crisis on Jordan, and analyzed Jordan's previous experiences in dealing with refugees from Palestine, Iraq and finally Syria.

- What distinguishes the current study from the previous studies is that it deals with the socio- political dimensions of the Syrian refugees crisis in Jordan, while the focus of most of the previous studies was on the economic and financial dimension, without taking into account other aspects and dimensions. The current study differs from the previous studies in that it deals with the dimensions of the crisis and its repercussions on Jordan socially and politically. The study is characterized by its modernity compared to previous studies, which became old studies exceeded by events and developments and the rapid changes in the Syrian crisis.

\subsection{Concepts of Study}

\subsubsection{Political Stability}

Political stability is defined as the ability of the regime to cope with the crises it faces successfully, and its ability to manage existing conflicts within the society in a way in which it can control it as required by the objectives and based on a legitimacy that does not resort to the use of political violence on the one hand and efficiency on the other. Political stability is flexible and requires the ability of the regime to employ its institutions to make the necessary changes to respond to the expectations of the masses, and contain the potential conflicts that may arise without the use of violence. The researchers define it as an act of stability of the Jordanian political system without any threats or challenges, internal or external.

\subsubsection{The Refugee}

The refugee is defined in accordance with the 1951 Convention relating to the Status of Refugees, as amended by the Protocol relating to the Status of Refugees of 1966, which entered into force in 1971 (Abdul Karim, 2008). The refugee is every person who's found outside of his country of nationality as a result of an act that has occurred and caused him to be persecuted because of his race, nationality, or political views, and cannot address or avoid such fear, shall be entitled to the protection of the country he flees to, "or any person who has no nationality and is outside his or her former habitual residence as a result of such events and cannot or does not want to return to that

\footnotetext{
${ }^{6}$ Doris Carrion, Syrian Refugees in Jordan: Confrontation Difficult Truths, Middle East and North Africa Programmer.2015.

${ }^{7}$ Solaf Tariq Abdul Karim, War and the principle of non-refoulement, Qadisiyah Journal of Political Science, Iraq, Vol. I, 2008.
} 
country.

\subsubsection{The Syrian Crisis}

The Syrian crisis began in 2011 as a part of the so-called Arab Spring revolutions that started in Tunisia and moved to Egypt, Libya, and Yemen. The Syrian protests were peaceful in the beginning, but the violent reaction of the Syrian regime and its rejection of political and economic reforms led to change the demands of the revolutionaries to overthrow the regime. The Syrian regime has failed to deal with the crisis, and the Arab system failed to find a solution to it, which led to the continuation of the crisis and the rise in the number of Syrian victims, between the dead, injured, and refugees.

\subsection{Jordan and Refugee Issues: Historical Background}

Jordan has a long history and rich experience in dealing with refugees and providing asylum to people who are oppressed religiously or politically. The Mediterranean geographical location of Jordan, the tolerant Arab-Muslim nature of Jordanians, and finally the nature of the Jordanian Hashemite political regime as inheritor of the Arab revolution and a home for all Arabs, all those factors attracted large numbers of refugees to the country throughout history up to the present.

Before the emergence of the modern state of Jordan, at the end of the eighteenth century and the beginning of the nineteenth century, Jordan had received waves of immigrants from Chechnya and Circassia who fled from Russia to protect their religion after the occupation of Russia to the Caucasus (Sukhneh, 2014) and in the early twentieth century, after the collapse of the Ottoman state and the fall of Arab rule in Damascus and the impose of the French mandate on Syria, Jordan witnessed the first wave of Syrian asylum to the country, where a large number of Syrian politicians arrived to Jordan, including Ali Reza Alrekabi, who later became prime minister in Jordan, in addition to many politician Syrians, especially members of the Syrian Independence Party, which occupied important political positions in Jordan (Khoury, 1987).

In 1925, when the great Syrian revolution started against the French occupation, and led by Sultan Pasha al-Atrash, the Syrian revolutionaries and the leader of the revolution, Sultan Pasha al-Atrash, took refuge in Jordan, where he was received by Jordanians as a national fighter and provided him with all possible assistance (Wilson, 1990). During the Great Palestinian Revolution of the mid-1930s, Jordan was the safe haven of many Palestinian revolutionaries who were persecuted by British Mandate authorities.

In 1948, following the outbreak of the first Arab-Israeli war -the Palestinian Nakba-, some 750,000 Palestinians were forced to emigrate. Jordan received the lion's share of them as a result of the historical, geographical and social ties between Jordan and Palestine. In 1951, Jordan has established the Ministry of Refugee Affairs to provide assistance or care to Palestinian refugees who have come to the country (Mishal, 1978).

With the establishment of the unity between the two banks in 1950, Jordan allowed the Palestinian refugees full integration into Jordanian society by granting them Jordanian nationality without detracting them from their legitimate historical rights of the rights return and compensation. Jordan has provided all these facilities to Palestinian refugees, although Jordan is not a party to the 1951 Convention relating to the Status of Refugees (Economic and Social Council ${ }^{2014) .}$

In 1967, Jordan was surprised by a new wave of Palestinian refugees following Israel's occupation of the entire West Bank, with nearly half a million people in Jordan, they made up a third of the population of the East Bank at the time (Bani Salameh and El-Edwan, 2016).

As Jordan is located in the heart of the Middle East, the least stable region in the world, it has been and remains the most vulnerable to migration with all the waves of conflict, violence and wars taking place in the region. Jordan hosted several thousand Lebanese during the civil war in Lebanon in the mid-1970s. And hosted several thousand Iraqis during the first Gulf War (1980-1988). In 1990, when Iraq invaded Kuwait, Jordan witnessed a

\footnotetext{
8 For more information about the immigration of Chechens and Circassians to Jordan see the following link: www.sukhneh.com/32-11-14-08-11-2014-b21

${ }^{9}$ Philip S. Khoury, Syria and the French Mandate: the Politics of Arab Nationalism 1920-1945.London:L.B.Touris and Co. LTD Publishers, 1987,pp220-227.

${ }^{10}$ Marry C. Wilson, King Abdullah,Britain, and the Making of Jordan, Cambridge University Press, 1990.P.89.

${ }^{11}$ Shaul Mishal, West Bank/ East Bank: The Palestinians in Jordan,1999-1967, the University Press, New Haven, 1978

${ }^{12}$ Economic and Social Council, A Study of the Effect of the Syrian Refugee Influx on the Jordanian Labour Market see the following link, http://www.esc.jo/Documents/79fd3414-8199-472a-8933-53eb9c08f1c0.p.8.

${ }^{13}$ Bani Salameh, M. T. and El-Edwan, K. I. (2016). The identity crisis in Jordan: historical pathways and contemporary debates, Nationalities Papers, 44:6, 985-1002, DOI: 10.1080/00905992.2016.1231454
} 
third wave of Palestinian asylum, where most of the Palestinians living in Kuwait and the Arab Gulf countries sought refuge in Jordan, which placed considerable strain on the infrastructure as well as significant changes in its demographic composition and national identity (Bani Salameh and El- Edwan, 2016).

With the US occupation of Iraq in 2003, Jordan has become the largest host of Iraqi refugees. Iraqi migration has been the largest refugee in the Middle East since the catastrophe of Palestine in 1948. The number of Iraqi refugees and residents in the country reached more than one million, $20 \%$ of the population with the consequent of many political, economic and social burdens (Al-Shiyab, 2009).

At the start of the so-called Arab Spring revolutions, most of which turned into devastating civil wars, Jordan received thousands of Arabs from Egypt, Libya and Yemen as a result of the deteriorating security situation in the former countries.

With the beginning of the Syrian revolution in 2011 and the beginning of Syrian emigration to neighboring countries, Jordan was at the forefront of countries that opened its doors to Syrian refugees fleeing the horrors of the war. Jordan continues to receive Syrian refugees collectively until they reach about 2 million people, (Approximately 650,000 people were registered as refugees (UNHCR, 2017). Here, it can be said that Jordan's reception of Syrian refugees since 2011 until today is a continuation of the historical experience in receiving refugee flows to the country.

In general, it is concluded that Jordan treats the refugees well if one considers the magnitude of refugees influx to it as a result of the continuing conflicts in the region and the modest amount of assistance provided by the international community.

\subsection{Syria and the Arab Spring}

The Syrian crisis is part of a wave of popular protests that swept through the Arab world in 2010 and 2011, which was called the Arab Spring, started from Tunisia and then moved to Egypt and then to Libya, Yemen, and to a lesser extent Jordan and Bahrain. These revolutions succeeded in overthrowing the rule of tyrants in Tunisia, Egypt, Libya and Yemen (Mark, Hass and Welesh, 2016).

Syria has not been exception to calls and demands of reform and democracy, especially that the Syrian regime is one of the most authoritarian regimes in the Arab world. Since President Hafez al-Assad took over power following a military coup in 1970, Assad established a strong regime based on the security grip, with the complete absence of public freedoms and the continuation of the state of emergency, after the death of Assad in 2000 , the power was handed over to his son Bashar, who maintained the existing system, where the family and its relatives dominated all parts of the state, and the absence of democracy and transparency and the spread of corruption (Lesh, 2005).

The Syrian crisis began in early 2011, by popular demonstrations in the city of Daraa south of the country, to protest against the ruling power practices in Syria, especially after the arrest and torture of a group of teenagers who wrote anti-regime graffiti on the walls, and that was an unprecedented challenge to the rule of Bashar al-Assad, and protest movement quickly spread in all parts of the country, it was initially peaceful protest movement calling for political, economic and social reforms and raise the banner of freedom, and as a result of the brutality of the regime in dealing with the protesters where they were confronted with live ammunition by Syrian security troops and intelligence services and militias loyal to the Syrian regime known Shbiha, the demands evolved into the overthrow of the regime, and turned from a peaceful revolution to an armed revolution (Kassab and Al-shami, 2016).

The violence in Syria has led the Arab League, the United Nations and the major powers to the adoption of resolutions and the formation of committees and the launch of Arab and international initiatives to resolve the crisis, but to no avail, especially in light of the Russian intervention in the crisis where Russia has repeatedly used the veto to prevent condemnation of the Syrian regime. Russia and Iran provided military, political and economic support to the Syrian regime, which made the crisis more complex. There is no sign on the horizon to

\footnotetext{
${ }^{14}$ Mohammad Bani Salameh and Khalid Edwan, the Identity Crisis in Jordan: historical pathways and contemporary debates, Journal of Nationalism and Ethnicity Vol.44,6,2016.doi=10.1080\%foo905992-2016.1231454.

${ }^{15}$ Ahmed Al-Shiyab, The Legal, Economic and Social Conditions of Iraqi Residents in The Hashemite Kingdom of Jordan.Refugees, displaced and forced migration research center, Yarmouk University, Irbid, Jordan, 2009, P.8.

${ }^{16}$ Syria Regional refugee response Jordan-UNHCR Data, 2017.

${ }^{17}$ Axandra. Mark L.Hass and David Welesh, The Arab Spring: The Hope and Reality of Uprisings, West View Press, 2nd Edition, 2016.

${ }^{18}$ David W. Lesh, The New lion of Damascus: Bashar al-asad and Modern Syria, Yale University Press, 2005.

${ }^{19}$ Robin Yassin Kassab and Leila Al-shami, Burning Country: Syrians in Revolution and War. Plauto Press, 2016.
} 
an end to the crisis, which enters the seventh year, and expected to continue for at least a decade, civil wars usually last for ten years, and there are many historical evidences to this fact ${ }^{(1)}$. With the escalation of violence between the Syrian regime and its allies (Russia, Iran and its political arm in Lebanon, Hezbollah), the Syrian opposition and its allies (the Free Syrian Army, the Islamic groups, Turkey, Qatar and Saudi Arabia), the Syrian crisis has become the greatest tragedy of our time, a shocking humanitarian disaster unprecedented in history, the death toll on both sides has risen, the revolution has turned into a civil war and the number of Syrian refugees has risen dramatically in neighboring countries (UNHCR, 2017).

The various Syrian opposition forces succeeded in controlling almost $70 \%$ of the Syrian territory and besieging the regime in Damascus and the cities of the coast (Dettmer, 2013). During this conflict, the conflicting parties committed many massacres and the regime had used chemical weapons more than once. The war killed more than half a million Syrian, and caused the displacement of more than (12) million Syrians from their homes, where more than (8) million people have taken refuge, and displaced more than (4) million at home, in addition to almost complete destruction of infrastructure in all areas of Syria (UNHCR, 2017).

Syria, Lebanon and Turkey have been among the most affected by the Syrian crisis. They host more than 6 million Syrian refugees and are burdened by hosting them. The international community has contributed little to help Syrian refugees or host countries

In the next part of this paper, we will try to shed light on the effects of the Syrian refugee crisis on Jordan politically, as Jordan is one of the largest refugee-hosting countries in the world in terms of refugee-to-population ratio.

\subsection{The Socio Political Implications of the Syrian Asylum Crisis on Jordan}

There is no doubt that the influx of hundreds of thousands of refugees into a country over a short period of time has had negative effects on all political, economic, social and environmental levels, Jordan is not an exception . (Bani Salameh , 2019a). Especially since Jordan is originally a country with limited resources and potentials and suffers from various political and economic problems. In this part of the paper, we will address the political implications, which have not been addressed in the previous studies; following is a brief discussion of the political implications of the crisis:

\subsubsection{Curtailing Reform and Democratization}

During the Arab uprisings, the Jordanian political regime was able to maintain its status quo and avoided making meaningful concessions (Bani Salameh, 2018). It exploited the Syrian crisis and the influx of refugees to remind local protesters and reformers of the possible adverse consequences. This curbed the Jordanian population's appetite for deep political change. Protests diminished and then nearly ceased; the process of reform and democratization retreated, and despotism and absolute rule became institutionalized under a regime of parliamentary and partisan pluralism (Bani Salameh and Elananzah, 2015).

Zaatri camp, established in 2012 to host Syrian refugees, saw a dramatic increase in population to become the world's second largest refugee camp behind Dadaab in eastern Kenya. At one point, it hosted some 150,000 refugees $(B B C, 2014)$. Movement out of the camp is loosely restricted, and many refugees have fled, though it is unknown to where and for what purpose. Even without intentions to do harm, they pose a threat to Jordanian society (Szparga, 2014). The camp has seen increasing crime, including prostitution and drug dealing, and numerous riots have erupted as a result of harsh desert and weather conditions. The camp has also become an incubator for diseases that had been eliminated in Jordan including tuberculosis and hepatitis (Asharq al-Awsat, 2013).

\footnotetext{
${ }^{20}$ Syria Regional Refugee Response,UNHCR, 2017.

${ }^{21}$ Jamie Dettmer, Syria Rebels: Radicalization and Division, Middle East institute, 2013.

${ }^{22}$ Syria Regional Refugee Response, UNHCR, 2017.

23 Mohammed Bani Salameh, "Political Reform in Jordan: Reality and Aspirations," World Affairs Journal, May 2018. https://doi.org/10.1177\%2F0043820018765373

${ }^{24}$ Mohammed Bani Salameh and Azzam Elananzah, "Constitutional reforms in Jordan: A critical analysis,” Digest of Middle East Studies, Fall 2015. https://doi.org/10.1111/dome.12068

${ }^{25}$ BBC News (London), Apr. 6, 2014.

${ }^{26}$ Andrew E. Szparga, “The Effects of the Syrian Refugee Crisis on Jordan's Internal Security,” Independent Study Project (ISP) Collection, SIT Study Abroad, Fall 2014.

${ }^{27}$ Asharq al-Awsat (London), May 19, 2013.
} 
With the influx of Syrian refugees, freedoms have been curtailed and the security services have expanded their control over public life to ensure quiet and stability (Barari, 2015). Thus, for example, the regime adopted a policy of restricting political parties and civil society organizations, similar to what happened with the unified Jordanian Front Party and the Islamic Action Front Part the political arm of the Muslim Brotherhood. (Bani Salameh and Hayajneh, 2019).

The Jordanian political system preferred to limit the strength of the Muslim Brotherhood and to retreat from democratic transformation, while keeping the channels of communication effective between the system and the Muslim Brotherhood (Bani Salameh, 2019b ). In the last few years, the regime attempted to fragment both political parties from inside and to fuel the organizational differences within them (the disagreement between the "doves" and the "hawks"), without direct confrontation with them. This communal split within those political parties, was exacerbated by the government's intervention, could have serious long-term implications for Jordanian society and politics. (Bani Salameh, 2019 b).

The refugee crisis also increased demonstrations and protests, and the country experienced many changes and reshuffling of governments: During the crisis, there were some ten governments. Last year, Jordan has witnessed unprecedented changes in government leadership and policy. These changes came in response to widespread public demonstrations against proposed economic reforms and increasingly sharp demands by citizens for more transparency and better government services. Public administration declined, government effectiveness weakened, and corruption increased. International bodies such as the World Bank, the World Economic Forum, Freedom House, and others have confirmed the decline in political stability in Jordan during the Syrian civil war (Global Economy, 2019).Moreover, the refugee crsis consolidated the dominance of the deep state in Jordan.

\subsubsection{Increased Militarization}

The Syrian crisis also led to declines in security. Syrian missiles and artillery shells landed several times in Jordanian cities and towns while Jordanian border posts were attacked by terrorist organizations resulting in Jordanian deaths and injuries. Increased smuggling and infiltration of weapons and contraband intensified the burden on the security services (Al-Jazeera TV, 2016). This in turn raised the state of alert regarding dormant terror cells as well as increased tension within Jordanian society.

Militarization of Jordan has increased as the ruling elites concluded that maintaining security and stability could only be achieved by the military and that other social institutions could be dispensed with. The former elites still dominate the different official political and economic positions in the state. (Aladwan, 2017). The ineffectiveness and corruption of the civil state apparatus has been highlighted, including in the education and health sectors. These sectors were subject to a campaign of doubt, leaving only the military as an institution with a good reputation. The results include an increase in military spending: Jordan now ranks fourth in the Arab world and eighth at the international level in military spending relative to national income (Jordan Military Expenditures, 2019), with military expenditure accounting for 18 percent of government spending.

\subsubsection{Deepening Jordan's Dependency}

Jordan relies heavily on foreign aid, especially from the United States, the European Union, and the Gulf Cooperation Council (GCC) countries. This has been a constraint on its foreign policy, which has often adapted to those of donor states (Brand, 1999).

As a result of the Syrian refugee crisis, Jordan has become even more dependent on the foreign aid necessary for economic development and for coping with the burdens of the Syrian refugee crisis. Pressure by the Gulf states for Jordan to intervene in the Syrian crisis and to take an anti-regime position has been particularly strong

\footnotetext{
${ }^{28}$ Hasan Barari, "Reform and the Dynamics of Instability in Jordan during the Arab uprisings," Perceptions, Center for Strategic Research of the Ministry of Foreign Affairs of the Republic of Turkey, Winter 2015, p. 73.

${ }^{29}$ Bani Salameh, M. T. and Hayajneh, A. (2019). How Jordan Can Cope

The End of the Syrian Civil War. Middle East Quarterly, Summer. https://www.meforum.org/58683/end-syrian-civil-war-jordan

${ }^{30}$ Bani Salameh, M. T. (2019b). Muslim Brotherhood and the Jordanian State: Containment or Fragmentation Bets? (1999-2018). Asian Journal of Comparative Politics. December.

31 “Jordan Political Stability," The Global Economy.com, 2019.

${ }^{32}$ Al-Jazeera TV (Doha), June 21, 2016.

33 “Jordan Military Expenditures,” Index Mundi, Charlotte, N. C., accessed Mar. 29, 2019.

${ }^{34}$ Laurie Brand, Jordan Inter-Arab Relations: The Political Economy of Alliance Making (New York: Columbia University Press, 1999), p. 38.
} 
(Waleed, 2014). This has placed Amman in a tight situation. On the one hand, it does not want to anger the Gulf states, but on the other, it has its own concerns about the Syrian rebellion, the opposition, and the transformations in the Arab world . Jordan is trying to continue holding a balanced position on an imbalanced regional scene, Jordan had to accommodate a complex set of interconnected, and often contradictory, interests of allies and regional influence. The balancing between those who call for toppling president Bashar Assad's regime and those supporting Assad internally, regionally and internationally, made Jordan walk a tightrope

Jordan's external relations have also been stalemated with pivotal countries such as Turkey and Iran. Syria is Jordan's only land crossing to Turkey and Europe. Even worse is the closure of the Iraqi border, making Jordan nearly isolated. The country's dependence is also very clear with regard to Islamists. The Gulf states have placed the Muslim Brotherhood on their lists of terrorist groups, increasing the pressure on Jordan to do likewise The Hashemite regime has been unable to maintain its traditional relationship with the Brotherhood, which it regards as being under control, while balancing its interests with the Gulf states, especially the United Arab Emirates (UAE). The Jordanian regime has created problems with the Muslim Brotherhood in order to relieve the tension of those pressures. (Bani Salameh, 2019b). Amman thus demanded that the Jordanian Brotherhood be separated from the Global Guidance Bureau in The highest decision making body in the Muslim Brotherhood, its headquarters in Egypt and most of its key figures are Egyptians.The separation is significant so as to prevent the external interference in Jordanian partisan organizations, in other words, to Jordanize the Jordanian branch of the Muslim Brotherhood and also called for a separation from Hamas. The group's Jordanian headquarters was closed on the pretext that it was unlicensed, and the regime imposed a siege on its political and social activities (Amis, 2012).

\subsubsection{Threats to National Identity}

National identity is one of the most sensitive and complex issues in Jordan. Since its creation in 1921until recently, Jordan adopted a pan-Arab orientation at both state and society levels (Anderson, 2005), the Jordanian national identity is continually changing, from conflicting and unstable religious, national, regional, and tribal identities to the failure of the state to achieve social integration and the creation of a national identity for citizens. In light of the fragility of this national identity, the concepts of security and stability emerge at the expense of the concepts of citizenship, democracy, and political reform. However, the Syrian crisis saw a surge of distinct Jordanian nationalist sentiments. Jordanians expressed dissatisfaction with the Syrian migration wave, which adversely affected their lives on all levels and which underscored the weakness of national, religious and social links between them and their Syrian "brothers." The crisis thus heralded the end of the Jordan's pan-Arab orientation. Having hosted revolutionaries from Syria and Palestine in the 1920s and 1930s, the kingdom retreated to its narrow tribal and local affiliations. Despair has spread among Jordanians as they stopped believing in the idea of "Arab nationalism" (Ryan, 2014).

The rapid influx of Syrian refugees has also increased Jordanians' fear of becoming a minority in their own country. From 1948 to date, including the arrival of approximately two million Syrians, the number of immigrants has exceeded the number of indigenous people. According to U.S. ambassador to Amman Alice Wells, as a result of successive waves of immigration, the indigenous proportion of the total population is as low as 27 percent. This caused a stir in Jordanian society, but at the same time raised the question of national identity as a new problem (Bani Salameh and El-Edwan, 2016). The national identity card has become one of the cards used by the regime to suit its interests, Jordanians are becoming paranoid because they feel outnumbered. Furthermore, since tribal identity is an essential driver of Jordanian society, Jordanians are less receptive to outsiders and subcultural identities (Haynes, 2016).

A number of Syrian refugees in Jordan have no desire to return home. Settling these refugees in Jordan will intensify as a result of international pressures, but such settlement will exacerbate the crisis of Jordanian national identity. Preserving Jordanian national identity will require reconsidering the policy of open borders. But the

\footnotetext{
${ }^{35}$ Mahmoud Khalid Waleed, "Where does Jordan stand on the Syrian crisis?” Middle East Monitor, Jan. 24, 2014.

${ }^{36}$ Bani Salameh, M. T. (2019b). Muslim Brotherhood and the Jordanian State: Containment or Fragmentation Bets? (1999-2018). Asian Journal of Comparative Politics. December.

${ }^{37}$ Jacob Amis, "The Jordanian Brotherhood in the Arab Spring," The Hudson Institute, Washington, D.C., Dec. $27,2012$.

${ }^{38}$ Betty S. Anderson, Nationalist Voices in Jordan: The Street and the State (Austin: University of Texas Press, 2005), pp 70-77.

${ }^{39}$ Curtis R. Ryan, "Jordanian Foreign Policy and the Arab Spring,” Middle East Policy Council, Spring 2014.

${ }^{40}$ Mohammed Bani Salameh and Khalid Edwan, "The identity crisis in Jordan: Historical pathways and contemporary debates," Journal of Nationalism and Ethnicity, Oct. 2016. DOI: 10.1080/00905992.2016.1231454

${ }^{41}$ W. Haynes, “Jordanian society's responses to Syrian refugees,” Military Review, Jan.-Feb. 2016.
} 
inability of the state to control its borders marginalizes the role of civil society in the face of successive refugee waves (Bani Salameh and El- Edwan, 2016).

In Jordan, as in other countries, national identity consists of system of beliefs, common values, assumptions, expectations, national symbols, memories and so on. In the Jordanian case, Jordanian national identity consists of tribes who play a central role in the identity of the majority of Transjordanians, commitment to Arabism, association with the monarchy, and distinctiveness from ther identity; namely the Palestinian, regardless the regime's efforts to develop a hybrid identity encompassing both Transjordaians and Palestinians. (Bani Salameh and Hayajneh, 2019).

\subsubsection{Increased Levels of Extremism and Terrorism}

Jordan experienced extremism and terrorism before the Syrian revolution, notably the Amman hotel bombings in 2005. The Jordanian state sought to combat the phenomenon by targeting youth at risk for multiple reasons such as poverty, unemployment, the failure of development projects, the absence of social justice, and the spread of corruption (Jordantimes, 2019).

After the Syrian revolution, terrorist organizations managed to spread extremist ideology, especially the Islamic State (ISIS), which, through its media apparatus, mobilized hundreds of Jordanians to its ranks. The number of Jordanians in extremist groups in both Iraq and Syria is estimated at three thousand (Policy Brief, 2019), and the security forces are pursuing dozens of people accused of joining or sympathizing with such organizations.

It was long believed that the majority of these were uneducated, marginalized, and poor, mainly from hardline and non-Jordanian families. But the intensification of the Syrian civil war has radicalized young people from different backgrounds - from the middle class or the bourgeoisie, from groups that historically have been bastions of regime support, and from different areas of the country. (Bani Salameh and Hayajneh, 2019). With the spread of jihadism in mosques, schools, and universities, extremist groups have become attractive to different groups and classes of society. Some have embraced jihadist ideology and have been trained and used in combat in Syria and Iraq (Abu Roman, 2019).

\subsubsection{High Rates of Corruption}

Corruption is one of the foremost challenges facing Jordan, with a highly negative impact on policies of reform, on development, and on stability. Combating corruption is a top priority for King Abdullah II, but the regime has not been successful to date (Transparency, 2019).

The Syrian crisis has led to an unprecedented spike in the scope of corruption, penetrating all aspects of political, economic, and administrative life (Jordan Times, 2017). In the last few years, the issue of corruption became at the forefront of Jordanian events, scandals of money -laundering, customs evasion, bribery, commission and assault on public money, especially in the official high circles or what is known as grand corruption, and other types of corruption point to the possibility that millions of dollars from the public capital may have been diverted to private accounts by Jordanian political elites. In sum, corruption is one of the most important challenges facing Jordan; it has a negative impact on the policies of reform, development and stability, many Jordanians believe that corruption is supported, backed, tolerated and practiced by the regime regardless of the discourse of fighting corruption and breaking its back. Perhaps one of the most prominent effects is the weakened prestige of the state as a result of individual corruption, especially by civil servants and among those in high official circles, what is known as "grand corruption" (Satloff and Schenker, 2013).

\footnotetext{
${ }^{42}$ Mohammed Bani Salameh and Khalid Edwan, "The identity crisis in Jordan: Historical pathways and contemporary debates," Journal of Nationalism and Ethnicity, Oct. 2016. DOI: 10.1080/00905992.2016.1231454

${ }^{43}$ Bani Salameh, M. T. and Hayajneh, A. (2019). How Jordan Can Cope

The End of the Syrian Civil War. Middle East Quarterly, Summer. https://www.meforum.org/58683/end-syrian-civil-war-jordan

${ }^{44}$ For more information about Jordan's efforts to fight corruption, see Jordan committed to stepping up action against corruption, at the following link http://www.jordantimes.com/news/local/jordan-committed-stepping-action-against-corruption accessed Apr. 1, 2019.

45 "From Jordan to Jihad: The Lure of Syria's Violent Extremist Groups," Policy Brief, Mercy Corps, Portland, Ore., accessed Apr. 1, 2019.

${ }^{46}$ Mohammed Abu Roman, "ISIS's Jordanian Tale" See the following link:

https://www.academia.edu/32662106/رواية_داعش_الأردنية_pdf accessed Apr. 1, 2019.

${ }^{47}$ See Corruption Perception Index at the following link https://www.transparency.org/news/feature/corruption_perceptions_index_2017 accessed Febr. 1, 2019,

${ }^{48}$ The Jordan Times (Amman), Jan. 26, 2017.

${ }^{49}$ Robert Satloff and David Schenker, "Political Instability in Jordan," Contingency Planning Memorandum, no.19, Council on Foreign Relations, New York, May 2013.
} 
Corruption has also been made more prevalent by the blatant state's favoritism of small and cohesive ruling elite, and its failure to carry out the necessary socioeconomic reforms to widen the national distribution of resources (Ryan, 2011). The government's ability to provide the basic requirements of life for citizens, such a food, water, housing, health, education, and legal services, has declined, while poverty, unemployment, marginalization, injustice, corruption, lack of oversight and accountability, have become widespread. Access to public services has become the main concern for citizens, but the ruling elite believes that relative privation prevents citizens from raising the level of demands. This sterile thinking has made the situation a ticking time bomb, with spreading poverty, unemployment, economic crises, low wages, and high prices creating an environment conducive to corruption. (Bani Salameh and Hayajneh, 2019).

Finally, with the decline of the democratization process, the political will to combat corruption has weakened, and the ability of government officials to act with little accountability has increased. Corruption is practiced by the influential in broad daylight and efforts to combat it have evaporated. This is confirmed by the reports on world corruption indicators (Jordan Times, 2017). The mutual relationship between the refugee crisis and corruption seems clear.

\subsubsection{The Threat of Security and Political Stability}

Wars and conflicts are the most damaging factors affecting security and stability, and the Syrian crisis is not an exception. The Syrian crisis has led to a decline in stability rates in the country. For example, Jordan suffered from the fall of missiles and rockets on cities and towns adjacent to Syria as a result of military operations between the forces of the regime and the opposition (Jordan Times, 2015). Some Jordanian border locations were directly attacked by the terrorist organization ISIS; resulting in deaths and injuries. The smuggling and infiltration of individuals, weapons, and contraband increased because of the lack of border control by regime forces, and it increased security burdens on the security services, which raised the state of alert to the security breaches to encounter radical organizations and sleeper cells of the militant groups. It also increased tension within the Jordanian society because of the repercussions of the Syrian crisis, and it increased the pace of informal violence of demonstrations, disturbances, and protests. Jordan suffered from frequent governmental changes during the years of the crisis; the government reshuffled nearly ten times, public administration declined, government effectiveness weakened, and corruption increased. According to the reports of international institutions concerned with the measurement of political stability rates, such as: the World Bank, the World Economic Forum, Freedom House, and others. The reports of these organizations confirmed the decline political stability rate in Jordan during the years of the Syrian crisis. The higher the rate of Syrian refugees in the country, the lower the rates of political stability (Jordan Times, 2015).

\subsubsection{Increasing Levels of State Fragility}

Despite the policies of economic liberalism and the cautious political openness adopted by the Jordanian regime during the past years (Masher, 2011), these policies, which were considered reformist, did not bring the desired outcomes, and they were not for the benefit of all citizens but for the benefit of a certain group of society. The state favors this group to be a small and cohesive ruling elite, especially in light of the abandonment by the state of its economic and social obligations and the decline of the process of political and democratic reform (Ryan, 2011). The decline of the state's ability to provide the basic requirements of life for citizens, such as: food, water, housing, health, education, and legal services appropriate to people's livelihood; with widespread poverty, unemployment, marginalization, injustice, corruption, lack of oversight and accountability, access to public services has become the main concern for citizens, where the ruling elite believe that it prevents citizens from raising the level of demands that they view above the need. This sterile thinking makes the situation a ticking time bomb exposed to an explosion at any time, if the state did not take appropriate actions and raise the level of the provided services and meet the citizens' needs. (Bani Salameh and Hayajneh, 2019).

\footnotetext{
${ }^{50}$ Curtis, R. Ryan, "Political Opposition and Reform Coalitions in Jordan,” British Journal of Middle East Studies, Vo1. 37 , No. 3 (2011).

${ }^{51}$ Bani Salameh, M. T. and Hayajneh, A. (2019). How Jordan Can Cope

The End of the Syrian Civil War. Middle East Quarterly, Summer. https://www.meforum.org/58683/end-syrian-civil-war-jordan

${ }^{52}$ The Jordan Times (Amman), Jan. 26, 2017.

${ }^{53}$ Missile from Syria damages Ramtha house, Jordan Times, Nov. 2015.

${ }^{54}$ Jordan political stability-data chart, Ibid.

${ }^{55}$ Marwan Masher, A Decade of Struggling Reform Efforts in Jordan: the Resilience of the Renter System, Middle East,May 2011.

${ }^{56}$ Curtis, R. Ryan, Political Opposition and Reform Coalitions in Jordan, British Journal of Middle East Studies, Vo1. 37 Issue 3, 2011.
} 


\subsubsection{Weakening National Sentiment and Strengthening Narrow and Sub-Affiliations}

Since the inception of the Jordanian state in 1921 until a short time, Jordan was at both the state and society level the most Pan- Arab country, based on the fact that Jordan is the heir to the message of the Arab revolution and in accordance with that was the philosophy of the regime, which raised the slogan Jordan is the country of all Arabs (Anderson, 2005).

The Syrian crisis has revealed a relapse of nationalist sentiment in among the Jordanian society, and eased national hopes in the popular conscience of Jordan, as if Jordan had pulled out of the realm of the national arena, when the official discourse of the state declares that the Syrian refugees are brothers to Jordanians based on the facts of history and geography, and the refugees are in distress and Jordanians must help them, but the reality revealed the depth of the gap between the ruling political elite and the Jordanian society in general, this could be explained by the fact that such elites lack understanding of the reality of society and his concerns and problems.

The Jordanian society expressed its dissatisfaction with the Syrian wave of asylum that affected its life, and had negative repercussions on all political, economic, social, security, demographic and health levels. The Jordanian citizen felt injustice, exclusion and marginalization. The crisis revealed the fragility and weakness of the national, religious and social links between Syrians and the Jordanians, the number of Syrians who came to their relatives in Jordan was very little.

The crisis also revealed the end of the generation of pioneers who clung to the Pan Arab ideology and national identity. They hosted the revolutionaries from Syria and Palestine in their homes in the 1920s and 1930s, furthermore, the society retreated to its narrow tribal and regional affiliations, and the narrow affiliations were strengthened. In the absence of a clear vision from the ruling elite about how to build and manage a national state, the lack of state-build-ing constantly affects tribal, sectarian, regional, and other loyal-ties that outweigh loyalty to the state. This is seen clearly in the continuation to the present day of pre-state practices, such as looting, robbery, and other crimes, which contribute to tension between state and society and hamper the mechanisms of reform and the establishment of moderninstitutions.(Bani Salameh,2017). Despair spread among Jordanians as if they stopped believing in the idea of Arab nationalism (Ryan, 2014).

\subsubsection{High Degree of Division and Polarization in Society}

The Syrian crisis has increased the division and polarization in Jordanian society. The Islamist in the country has declared their support for the Syrian revolution, asserting the right of the Syrian people to freedom, dignity and life. The leftist and Pan -Arab nationalist parties declared their support for the Syrian regime, considering that the Syrian revolution is an external conspiracy aimed at weakening Syria and serving the foreign imperialist interests, primarily Israel, as the Syrian regime refuses to reconcile with Israel and supports the national resistance in Palestine and Lebanon (Ryan, 2014). The state of political and ideological polarization in society confused the Jordanian political scene, and have had repercussions on the Jordanian society, and perhaps form the foundation stone for further division and polarization, and increase tension and instability in the future.

\section{Conclusions and Recommendations}

This study dealt with the socio-political implications of the Syrian asylum crisis on Jordan. So, the study dealt with the beginning of Jordan's historical experience in dealing with refugee issues. It also dealt with Syria and the Arab Spring revolutions. The study then went on to explain the most prominent socio- political effects of the Syrian asylum on Jordan. We do not want to repeat here what was mentioned in the previous pages, but here we would like to crystallize some important issues as follows:

First: Whatever the economic losses caused by the Syrian refugee crisis are great, the socio-political losses that have hit the state and society are greater and more important. Jordan has lost the efforts and sacrifices made in terms of reform, strengthening democracy, building national identity, fighting violence and extremism, combating corruption and adhering to Pan Arab dream. These are costly and far-reaching losses that will extend beyond the end of the Syrian crisis and cannot be reckoned with quickly or impulsively.

Second: The Syrian asylum crisis in Jordan is essentially a crisis of participation in decision-making, public policy, and can be dealt with only in the framework of a new approach of governance and policy making, taking into account the principles and values of broad political participation, dialogue, national consensus and the wishes of the citizens who are the essence and core of very development and stability. The deep-rooted

\footnotetext{
${ }^{57}$ Betty S. Anderson, Nationalist Voices in Jordan: The Street and the State, University of Texas Press, 2005.

${ }^{58}$ Curtis R. Ryan, Jordanian Foreign Policy and the Arab Spring. Middle East Policy Council. Vol. XXI. No.1 Spring. 2014.

${ }^{59}$ Ryan, Jordanian Foreign Policy and the Arab Spring, Ibid.
} 
exclusionary policies that have been practiced prior to the Syrian crisis are like a state of political upheaval which marginalized large segments of society preventing them from a participating effectively in decision-making in critical crucial issues such as the Syrian asylum crisis.

Third: The results of the study showed that the Syrian asylum crisis revealed many socio-political defects and distortions in the political structure of the state, such as the fragility of the democratic experiment, the weakness of the national identity, the decline of citizens' trust in the state and its institutions, and the rampant of corruption, mismanagement and other distortions.

These distortions have deep roots in the structure of the Jordanian state, and had been revealed and exacerbated by the arrival of Syrian refugees. These are deep and long-standing cracks in the country's political, economic and social infrastructure.

Fourth: The results of this study revealed that the Jordanian state, despite its rich historical experience in dealing with asylum issues, it lacked an effective national strategy to deal with the Syrian refugee crisis. Most of the policies were based on reactions, which led to an increase in citizens' lack of confidence of their state, widening the gap between Who governs and who are governed, revealing a crisis in governance, and prompted many citizens to demand that the State of Jordan to stop the application of open door policies to the influx of Syrian refugees to the country.

\subsection{Recommendations}

Based on the findings of this study on the socio- political effects of the Syrian asylum crisis in Jordan, and on the basis of concern for the interests of the country and citizens, and the necessity to reconsider the approach of exclusionary rule, which left a wide range of Jordanian society absent, widening the gap between the current situation and popular aspirations, and in order to transform the Syrian asylum crisis into an opportunity to evaluate the experience and to reduce the negative effects of the Syrian asylum crisis, this study recommends that:

1) Put the concerned politicians, thinkers, researchers and decision-makers at the political, economic and media levels in Jordan with the results of this study and take lessons and advice from them.

2) The necessity to conduct more research and studies in this area more accurately to identify the effects of the Syrian refugee crisis, weaknesses and shortcomings in dealing with the crisis to find out the reasons for this failure and to search for treatment,so that these studies support the efforts in dealing with the crisis of Syrian asylum.

3) Enhancing public freedoms and encouraging the media to play the assigned role to cover and follow up the effects of the Syrian refugee crisis and provide daily or weekly information programs that highlight the various dimensions of the Syrian refugee crisis and avoid as far as possible the traditional methods of favoritism of the government as such practices lead to citizens to avoid and ignore such programs.

4) Addressing the international community to recognize the great role that Jordan plays in hosting Syrian refugees and providing necessary assistance to the Jordanian government and international organizations working in the field of refugees, and Jordan must stress the need to end the war and the return of Syrian refugees to their country.

5) Reconsidering the national strategy to combat extremism, terrorism and corruption and inviting clerics to give these subjects their utmost attention to form a religious awareness that denies extremism and corruption.

6) The need to limit the factors that negatively affect the national and constants, which led to the decline of faith in the national dream and the promotion of narrow loyalties between sectarian or regional or tribal, these deposits seriously affect the environment of the community and the form of relations of individuals and may extend their effects for years.

7) To promote democracy in Jordan and to achieve genuine political reform by promoting the values of participation, transparency, accountability, combating corruption, and renouncing violence and extremism.

\section{Acknowledgments}

This article builds on and considerably expands and updates an earlier work by Mohammed Bani Salameh and Ayman Hayajneh, titled: The End of the Syrian Civil War How Jordan Can Cope. June 2019 Middle East Quarterly, 26(3), 1-9. Available from: https://www.meforum.org/58683/end-syrian-civil-war-jordan.

\section{References}

Abdul Karim, S. T. (2008). War and the principle of non-refoulement. Qadisiyah Journal of Political Science, 
Iraq, $I$.

Abu-Odeh, A. (1999). Jordanians, Palestinians and the Hashemite Kingdom In the Middle East Peace Process. United State Institute of Peace Press, Washington, D.C.

Adwan, K. et al. (2018). Elite Circulation: Case Study of the Jordanian Parliament. Dirasat Journal, 45(4).

Ake, C. (1975). A Definition of Political Stability. Comparative Politics, 7(2).

Al- Shiyab, A. (2009). The Legal, Economic and Social Conditions of Iraqi Residents in The Hashemite Kingdom of Jordan. Refugees, displaced and forced migration research center, Yarmouk University, Irbid, Jordan.

Al-Jazeera, T. V. (2016). Doha, June 21.

Al-Shaarawi, T. I. (2016). The General Situation of Jordan in Light of the Syrian Refugee Crisis. Barq Center for Research and Studies, Amman, Jordan. Retrieved from www.barq-rs.com/barq/1768-2

Amis, J. (2012). The Jordanian Brotherhood in the Arab Spring. The Hudson Institute, Washington, D.C., Dec. 27.

Anderson, B. S. (2005). Nationalist Voices in Jordan: The Street and the State, University of Texas Press.

Asharq al-Awsat. (2013). London, May 19.

Bani Salameh, M. T. (2017). Political Reform in Jordan: Reality and Aspirations. World Affairs Journal, 180. https://doi.org/10.1177\%2F0043820018765373

Bani Salameh, M. T. (2019a). Migration from Arab Spring Countries to Europe: Causes and Consequences. IEREK Interdisciplinary Series for Sustainable Development.The $1^{\text {st }}$ American University in the Emirates International Research Conference, UAE, Dubai, Nov.15, 2017.

Bani Salameh, M. T. (2019b). Muslim Brotherhood and the Jordanian State: Containment or Fragmentation Bets? (1999-2018). Asian Journal of Comparative Politics. December. https://doi.org/10.1177/2057891119891035

Bani Salameh, M. T., \& Alkatatsheh, M. H. (2019). The Politics of Migration from the Arab Spring Countries to Europe. Dirasat: Human and Social Sciences, 46(4), 2019-106.

Bani Salameh, M. T., \& Ananza, A. (2015). Constitutional Reforms in Jordan: A Critical Analysis. Digest of Middle East Studies, 24(2). https://doi.org/10.1111/dome.12068

Bani Salameh, M. T., \& El-Edwan, K. I. (2016). The identity crisis in Jordan: historical pathways and contemporary debates. Nationalities Papers, 44: 6, 985-1002.

Bani Salameh, M. T., \& Hayajneh, A. (2019). How Jordan Can Cope. The End of the Syrian Civil War. Middle East Quarterly, Summer. Retrieved from https:/www.meforum.org/58683/end-syrian-civil-war-jordan

Barari, H. (2015). Reform and the Dynamics of In/ Stability in Jordan during the Arab Uprisings. Perceptions, $x x(4), 73$.

BBC News. (2014). London, Apr. 6.

Brand, L. (1999). Jordan inter Arab Relations: The Political Economy of Alliance Making. New York: Columbia University Press.

Carrion, D. (2015). Syrian Refugees in Jordan: Confrontation Difficult Truths. Middle East and North Africa Programmer.

Corruption continues to plague Jordan and 5 steps to fighting it. Retrieved from www.Black-iris.com/.../curruption-continuesto-plague-Jordan-and5steps

Dettmer, J. (2013). Syria Rebels: Radicalization and Division. Middle East institute.

Economic and Social Council, A Study of the Effect of the Syrian Refugee Influx on the Jordanian Labour Market. Retrieved from http://www.esc.jo/Documents/79fd3414-8199-472a-8933-53eb9c08flc0

Eric, S., \& Hillesund, S. (2015). Impact of Syrian Refugees on the Jordanian Labor Market. International Labor Organization and FAFO, April.

Frankens, J. (2014). Evaluating the Effects of the Syrian Refugee Crisis on Stability and Resilience in Jordan: Host Communities Preliminary Impact Assessment. Retrieved from https://data.inhcr.orgtsyrianrctugees/downloadphp/

Haynes, W. (2016). Jordanian society's responses to Syrian refugees. Military Review, Jan.-Feb. 
Jordan committed to stepping up action against corruption. Retrieved from http://www.jordantimes.com/news/local/jordan-committed-stepping-action-against-corruption

Jordan militant expéditeurs. Retrieved from www.indexmundi.com/jordan/militany-expenditures-html

Jordan political stability-data chart: The global Economy.com. Retrieved from www.theglobaleconomy.com/Jordan/wb-political-stability

Jordan solders killed in Syria border bomb attack-News on. Retrieved from Www.aljazera.com/.../jordan-solders-killed-syrian-border-bomb-attack

Jordan Times. (2015). Missile from Syria damages Ramtha house, Nov.

Jordan to jihad/the lure of Syria violent extremist groups. Retrieved from http://mercygroups.org/sites/default/files/from\%20jordan\%20to\%20jihad-o.pdf

Jordan: One of the Most Militarized Nations on Earth: black-iris.com.

Kassab, R. Y., \& Al-Shami, L. (2016). Burning Country: Syrians in Revolution and War. Plauto Press.

Khalid Waleed, Mahmud, where does Jordan stand on the Syrian crisis? Retrieved from http://www.middleeastmonitor/2014/24/

Khoury, P. S. (1987). Syria and the French Mandate: the Politics of Arab Nationalism 1920-1945. London: L.B. Touris and Co. LTD Publishers, pp. 220-227.

Lesh, D. W. (2005). The New lion of Damascus: Bashar al-asad and Modern Syria. Yale University Press.

Mark, A., Hass, L., \& Welesh, D. (2016). The Arab Spring: The Hope and Reality of Uprisings (2nd ed.). West View Press.

Masher, M. (2011). A Decade of Struggling Reform Efforts in Jordan: the Resilience of the Renter System. Middle East, May.

Mishal, S. (1978). West Bank/ East Bank: The Palestinians in Jordan, 1999-1967. The University Press, New Haven.

Mohammed Abu Roman, "ISIS's Jordanian Tale". Retrieved from

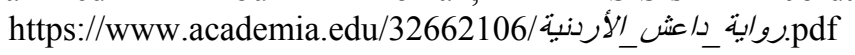

Nasser, R., \& Symansky, S. (2015). The Fiscal Impact of the Syrian Refugee Crisis on Jordan. United States Agency for International Development Jan 5.

Ryan, C. R. (2011). Political Opposition and Reform Coalitions in Jordan. British Journal of Middle East Studies, $37(3)$.

Ryan, C. R. (2014). Jordanian Foreign Policy and the Arab Spring. Middle East Policy Council, XXI(1).

Satloff, R., \& Schenker, D. (n.d.). Political Instability in Jordan. Contingency Planning Memorandum, no.19, Council on Foreign Relations, New York, May.

Szparga, A. E. (2014). The Effects of the Syrian Refugee Crisis on Jordan's Internal Security. Independent Study Project (ISP) Collection, SIT Study Abroad, Fall.

The Jordan Times. (2017). Amman, Jan. 26.

UNHCR. (2017). Syria Regional refugee response Jordan.

Waleed, M. K. (2014). “Where does Jordan stand on the Syrian crisis?” Middle East Monitor, Jan. 24.

Wilson, M. C. (1990). King Abdullah,Britain, and the Making of Jordan. Cambridge University Press.

\section{Notes}

Note 1. Civil wars usually last at least for a decade, for example: the Algerian civil war 1990-2003, the Sudanese civil war 1983-2005 and the Lebanese civil war 1975-1990.

\section{Copyrights}

Copyright for this article is retained by the author(s), with first publication rights granted to the journal.

This is an open-access article distributed under the terms and conditions of the Creative Commons Attribution license (http://creativecommons.org/licenses/by/4.0/). 